\title{
Assessment of Genetic Divergence in Chilli (Capsicum annuum L.) Genotypes
}

\author{
Priyanka Bijalwan*, Meghana Singh and Naidu Madhavi
}

V.C.S.G. Uttarakhand University of Horticulture and Forestry, Bharsar (246123), College of Forestry, Ranichauri Tehri-Garhwal (Uttarakhand), India

*Corresponding author

\section{A B S T R A C T}

\section{Keywords}

Capsicum annuum $\mathrm{L}$. Intra cluster, Inter cluster, Cluster mean, Genetic diversity

Article Info

Accepted:

12 February 2018 Available Online: 10 March 2018
Study on Genetic Diversity was conducted with 16 chilli (Capsicum annuum L.) genotypes at the field of Vegetable Research Block of V.C.S.G. Uttarakhand University of Horticulture and Forestry, Ranichauri Campus Tehri- Garhwal during Kharif2014. Genetic diversity among 16 chilli genotype was worked out usingD ${ }^{2}$ statistic. On the basis of genetic distance, these genotypes were grouped into 5 clusters. Cluster I was largest, consisting of nine genotypes followed by cluster II with four genotypes while cluster III, IV and V contained single genotype each. There was no parallelism between genetic diversity and geographical distribution. The maximum inter cluster distance was found between cluster III and cluster V and minimum was found between cluster III and cluster IV. The character ascorbic acid content contributed maximum towards divergence. Considering diversity pattern and other performance of the genotypes UHF-C-13-2, UHFC-12-4, Kashmiri Long and UHF-C-13-4 from cluster II, genotype UHF-C-12-1 from cluster V, UHF-C-13-6 from cluster IV may be taken into consideration as better parents for an efficient hybridization programme of chilli.

\section{Introduction}

Chilli (Capsicum annuum L.) is used as spice not only in India but also throughout the world on account of its pungency and pleasant flavour. Through consumption in small amount enriches our diet as and considered good sources of minerals, vitamins and other food components. Almost all the varieties of low and medium pungency cultivated on a field scale in India are belonged to Capsicum annuum L. A number of cultivars are grown in India differing in habit, yield and consumer's preference and in size, shape, colour and pungency of the fruit. India is the world leader in chilli production with total area of 7.75 lakh hectare and production of 14.92 lakh tones next only to China and Pakistan (Anon, 2014).

Assessment of different desirable traits spread over diverse genotypes is important to rapid advance in yield improvement of any crop. The importance of genetic diversity in the improvement of a crop has been studied in both self and cross pollinated crop (Griffring and Lindstrom, 1954; Murthy and Anand, 1966; Gaur et al., 1978). The plant breeders are always interested to know the genetic 
divergence among the varieties available due to reasons that crosses between genetically diverse parents are likely to produce high heterotic effect (Ramanujam et al., 1974) and crosses involving distantly related parents within the same species produce wide spectrum of variability. A logical way to start any breeding programme is to collect precise information on the nature and degree of genetic divergence that would help the plant breeder in choosing the right type of parents for purposeful hybridization in heterosis breeding (Patel et al., 1989). Moreover, evaluation of genetic diversity is important to know the source of genes for a particular trait within the available germplasm (Tomooka, 1991).

The utility of multivariate analysis for measuring the degree of divergence and for assessing the relative contribution of different characters to the total divergence in selfpollinated crops has been established by several workers (Das and Gupta, 1984; Natarajan et al., 1988; Sindhu et al., 1989 and Golakia and Makne, 1992). This experiment was undertaken to study genetic diversity and selection of suitable genotypes for future hybridization programme.

\section{Materials and Methods}

A total sixteen genotypes of chilli (Capsicum annuum L.) collected from various Institutes of India and different villages of TehriGarhwal district. The experiment was conducted at Vegetable Research Block of Veer Chandra Singh Garhwali Uttarakhand University of Horticulture and Forestry, Ranichauri Campus, Tehri-Garhwal during Kharif 2014. The experiment was laid out in randomized block design (RBD) with three replications. 47 days old seedlings were transplanted at spacing of $45 \times 45 \mathrm{~cm}$. Manure and fertilizers were applied as per recommended dose. Data on the characters plant height at $50 \%$ flowering $(\mathrm{cm})$, days to $50 \%$ flowering, days to first picking, leaf area $\left(\mathrm{cm}^{2}\right)$, number of branches per plant, fruit length $(\mathrm{cm})$, fruit diameter $(\mathrm{cm})$, pedicel length $(\mathrm{cm})$, pericarp thickness $(\mathrm{mm})$, dry matter content (\%), ascorbic acid content (mg/100 g fruit), plant height at last picking (cm), number of fruits per plant, fruit weight at edible maturity $(\mathrm{g})$ and fruit yield per plant (g) were recorded on individual plant basis from the ten plants selected at random per plot. The genetic divergence was calculated according to Mahalanobis $\mathrm{D}^{2}$ statistics (1936).

\section{Results and Discussion}

The analysis of variance revealed significant differences among the genotypes for all the characters studied indicating considerable amount of genetic variability for all the characters and thereafter the diversity analysis was carried out.

The computation from co-variance matrix gave non-hierarchical clustering based on Mahalanobis $\mathrm{D}^{2}$ values among 16 genotypes and grouped them into five clusters. The clusters occupied by 16 genotypes of chilli are presented in Table 1. It explained that cluster I was largest with nine genotypes followed by cluster II with four genotypes and cluster III, IV and V with one genotype in each. Group constellation of chilli genotypes through genetic divergence has also been reported by Farhad et al., (2010), Kumai et al., (2010), Chattopadhyay et al., (2011), Gogate et al., (2011), Peeraullee and Sanmukhiya (2013) and Yatung et al., (2014).

The cluster II earned the highest cluster mean values for days to $50 \%$ flowering, leaf area, fruit length, fruit diameter, pedicel length and fruit weight at edible maturity whereas, cluster $\mathrm{V}$ had highest value for number of branches per plant, ascorbic acid content, number of fruits per plant and fruit yield per plant. 
Table.1 Clustering pattern of 16 genotypes of chilli on the basis of genetic divergence

\begin{tabular}{|c|c|l|}
\hline Cluster & $\begin{array}{c}\text { Number of } \\
\text { genotypes }\end{array}$ & \multicolumn{1}{|c|}{ Name of genotypes } \\
\hline I & $\mathbf{9}$ & $\begin{array}{l}\text { Pant C-1, UHF-C-12-5, UHF-C-13-1, UHF-C-12-3, UHF-C- } \\
\text { 13-3, UHF-C-12-2, UHF-C-12-6, UHF-C-13-7, PusaJwala }\end{array}$ \\
\hline II & $\mathbf{4}$ & UHF-C-13-2, UHF-C-12-4, Kashmiri Long, UHF-C-13-4 \\
\hline III & $\mathbf{1}$ & PusaSadabahar \\
\hline IV & $\mathbf{1}$ & UHF-C-13-6 \\
\hline $\mathbf{V}$ & $\mathbf{1}$ & UHF-C-12-1 \\
\hline
\end{tabular}

Table.2 Intra cluster group means for various components of fruit yield in chilli

(Capsicum annuum L.)

\begin{tabular}{|c|c|c|c|c|c|c|}
\hline S. No. & Characters & \multicolumn{5}{|c|}{ Cluster Means } \\
\hline & & I & II & III & IV & V \\
\hline $\mathbf{1 .}$ & Plant height at 50\% flowering $(\mathrm{cm})$ & 40.122 & 40.317 & 37.300 & 40.633 & 35.867 \\
\hline $\mathbf{2 .}$ & Days to 50\% flowering & 80.037 & 71.833 & 102.000 & 99.000 & 97.667 \\
\hline $\mathbf{3 .}$ & Days to first picking & 109.333 & 110.250 & 119.333 & 115.000 & 112.667 \\
\hline $\mathbf{4 .}$ & Leaf area $\left(\mathrm{cm}^{2}\right)$ & 32.715 & 35.223 & 34.423 & 17.563 & 28.040 \\
\hline $\mathbf{5 .}$ & Number of branches per plant & 7.581 & 7.192 & 5.667 & 5.867 & 9.567 \\
\hline $\mathbf{6 .}$ & Fruit length $(\mathrm{cm})$ & 8.610 & 10.019 & 5.477 & 7.403 & 9.857 \\
\hline $\mathbf{7 .}$ & Fruit diameter $(\mathrm{cm})$ & 1.398 & 1.668 & 1.333 & 1.160 & 1.367 \\
\hline $\mathbf{8 .}$ & Pedicel length $(\mathrm{cm})$ & 4.567 & 5.637 & 4.843 & 3.990 & 4.700 \\
\hline $\mathbf{9 .}$ & Pericarp thickness $(\mathrm{mm})$ & 1.233 & 1.567 & 1.843 & 1.250 & 1.173 \\
\hline $\mathbf{1 0 .}$ & Dry matter content $(\%)$ & 11.408 & 10.967 & 12.000 & 14.877 & 10.883 \\
\hline $\mathbf{1 1 .}$ & Ascorbic acid content $(\%)$ & 143.407 & 184.932 & 149.733 & 149.947 & 269.887 \\
\hline $\mathbf{1 2 .}$ & Plant height at last picking $(\mathrm{cm})$ & 70.359 & 68.692 & 56.767 & 64.100 & 65.033 \\
\hline $\mathbf{1 3 .}$ & Number of fruits per plant & 70.619 & 65.767 & 36.867 & 50.067 & 106.733 \\
\hline $\mathbf{1 4}$. & Fruit weight at edible maturity $(\mathrm{g})$ & 2.771 & 5.112 & 1.833 & 2.013 & 3.583 \\
\hline $\mathbf{1 5}$ & Fruit yield per plant $(\mathrm{g})$ & 188.083 & 272.863 & 59.287 & 125.073 & 353.307 \\
\hline & & & & & & \\
\hline
\end{tabular}

Table.3 Intra (diagonal) and inter cluster $\sqrt{ } \mathrm{D}^{2}$ values among 16 genotypes of chilli (Capsicum annum L.)

\begin{tabular}{|c|c|c|c|c|c|}
\hline & I & II & III & IV & V \\
\hline I & 1058.072 & 1681.570 & 1387.608 & 1988.181 & 4053.983 \\
\hline II & & 1149.143 & 2834.375 & 3731.044 & 2565.571 \\
\hline III & & & 0.000 & 1262.368 & 4797.525 \\
\hline IV & & & & 0.000 & 4772.020 \\
\hline V & & & & & 0.000 \\
\hline
\end{tabular}


Table.4 Contribution of different plant growth and fruit yield characters to total divergence in chilli (Capsicum annuum L.)

\begin{tabular}{|c|c|c|c|}
\hline S. No. & Characters & $\begin{array}{c}\text { Number of times } \\
\text { appearing first in ranking }\end{array}$ & $\begin{array}{c}\text { Percent } \\
\text { contribution }\end{array}$ \\
\hline $\mathbf{1 .}$ & Plant height at 50\% flowering $(\mathrm{cm})$ & 0.01 & 0.00 \\
\hline $\mathbf{2 .}$ & Days to 50\% flowering & 16 & 13.33 \\
\hline $\mathbf{3 .}$ & Days to first picking & 0.01 & 0.00 \\
\hline $\mathbf{4 .}$ & Leaf area $\left(\mathrm{cm}^{2}\right)$ & 10 & 8.33 \\
\hline $\mathbf{5 .}$ & Number of branches per plant & 0.01 & 0.00 \\
\hline $\mathbf{6 .}$ & Fruit length $(\mathrm{cm})$ & 8 & 6.67 \\
\hline $\mathbf{7 .}$ & Fruit diameter $(\mathrm{cm})$ & 0.01 & 0.00 \\
\hline $\mathbf{8 .}$ & Pedicel length $(\mathrm{cm})$ & 0.01 & 0.00 \\
\hline $\mathbf{9 .}$ & Pericarp thickness $(\mathrm{mm})$ & 0.01 & 0.00 \\
\hline $\mathbf{1 0 .}$ & Dry matter content $(\%)$ & 22 & 18.33 \\
\hline $\mathbf{1 1 .}$ & Ascorbic acid content $(\mathrm{mg} / 100 \mathrm{~g}$ fruit) & 28 & 23.33 \\
\hline $\mathbf{1 2}$ & Plant height at last picking $(\mathrm{cm})$ & 0.01 & 0.00 \\
\hline $\mathbf{1 3 .}$ & Number of fruits/plant & 5 & 4.17 \\
\hline $\mathbf{1 4}$ & Fruit weight at edible maturity $(\mathrm{g})$ & 6 & 5.00 \\
\hline $\mathbf{1 5}$ & Fruit yield per plant $(\mathrm{g})$ & 25 & 20.83 \\
\hline
\end{tabular}

Cluster IV had highest value for plant height at 50\% flowering and dry matter content while cluster I was promising for plant height at last picking and days to first picking, Cluster III was found promising to pericarp thickness (Table 2). Variable cluster means for different plant growth and fruit yield characters have also been reported by Smitha and Basavaraja (2006), Ajjapplavara (2009), Farhad et al., (2010), Gogate et al., (2011) and Yatung et al., (2014) in chilli.

According to Mahalanobis's $\mathrm{D}^{2}$ statistic the intra and inter cluster distance $\left(\mathrm{D}^{2}\right)$ values are presented in Table 3. Results indicated that the highest intra-cluster distance $\left(\sqrt{ } D^{2}\right)$ was found for cluster II followed by cluster I.

The intra-cluster $\sqrt{ } D^{2}$ value in cluster III, IV and $\mathrm{V}$ was zero because these clusters consisted of only one genotype in each. The highest inter cluster distance was found between cluster III and cluster V followed by cluster IV and cluster V, cluster I and cluster
$\mathrm{V}$ and cluster II and cluster IV. Minimum inter-cluster distance was observed between cluster III and cluster IV (Table 3).

A wide range of inter-cluster genetic distance among the different clusters of chilli genotypes have also been reported by Smitha and Basavaraja (2006) from 72.34 to 453.16 , Farhad et al., (2010) from 13.88 to 21.77, Kumari et al., (2010) from 856.71 to 87774.02 and Yatung et al., (2014) from 36.04 to 459.81 .

The relative contribution of different characters depicted that ascorbic acid content contributed maximum towards genetic divergence followed by fruit yield per plant, dry matter content, days to $50 \%$ flowering, leaf area and fruit length. Fruit weight at edible maturity and number of fruits per plant exhibited relatively lower contribution to divergence and rest of characters exhibited nil contribution to total genetic distance (Table 4). 
Genotypically distant parents are able to exert high heterosis (Falconer, 1960). In the view higher inter-cluster genetic distance $\left(\sqrt{ } D^{2}\right)$ between cluster III and cluster V, cluster IV and cluster V and cluster II and cluster IV had higher cluster means for most of the desirable traits in these clusters cross combinations viz., Pusa Sadabahar $\times$ UHF-C-12-1, UHF-C-13-6 $\times$ UHF-C-12-1, UHF-C-13-6 × UHF-C-13-2, UHF-C-13-6 $\times$ UHF-C-12-4, UHF-C-13-6 $\times$ Kashmiri Long and UHF-C-13-6 × UHF-C13-4 are recommended for developing progeny with high vigour and desirable traits in chilli.

\section{References}

Ajjapplavara, P. S. 2009. Genetic diversity in chilli (Capsicum annuum L.). The Asian J. Hort. 49(1): 29-31.

Anonymous, 2014. Annual Report of National Horticulture Board, Gurgaon, www.nhb.org.in

Chattopadhyay, A., Sharangi, A. B., Dai, N. and Dutta, S. 2011. Diversity of Genetic Resources and Genetic Association Analysis of Green and Dry Chillies of Eastern India. Chilean J. Agric. Res. 71(3): 350-56.

Das, P. K. and Gupta, T. D. 1984.Multivariate analysis in blackgram. Indian J.Genet. 44(2): 243-47.

Falconer, D.S. 1960. Introduction to quantitative genetic oliver and $\mathrm{B}$ London.pp. 304.

Farhad, M., Hasanuzzaman, M., Biswas, B. K., Arifuzzaman, M. and Islam, M. M. 2010.Genetic divergence in chilli (Capsicum annuum L.). Bangladesh Res. Pub. J. 3(3): 1045-51.

Gaur, P.C., Gupta, P. K. and Kishore, H. 1978. Studies on genetic divergence in potato.Euphytica.27: 361-68.

Gogate, S. M., Patel, R. K., Patel, M. J. and Patel, A. 2011.Genetic Divergence in
Chilli (Capsicum annuum var. Longum (D. C.) Sendt.).Veg. Sci. 33(1): 21-25.

Golakia, P.R. and Makne, V. G. 1992.D ${ }^{2}$ analysis in Virginia runner groundnut genotypes.Ind. J. Genet. 55(3): 252-56.

Griffing, B. and Lindstorm, E. W. 1954. A study of combining abilities of corn inbreds having varying proportions of corn belt and non-corn belt germplasm. Agron. J. 46: 545-52.

Kumari, S. S., Jyothi, K. U., Shrihari, D.,Sankar, A. S. and Sankar, C. R. 2010.Variability and Genetic Divergence in paprika (Capsicum annuum L.).Journal of Spices and Aromatic Crops. 19(1\&2): 71-75.

Mahalanobis, P.C. 1936.On the generalized distance in statistics. Proc. Nalt. Inst. Sci. India.2: 49-55.

Murthy, B. and Anand, I. J. 1966.Combining ability and diversity in some varieties of Linum usitatissimum. Ind. J. Genet.26: 21-36.

Natarajan, C, Thiyagarajan, K. and Rathanaswamy, R. 1988. Association and genetic diversity studies in greengram. Madras Agric. J. 75(7-8): 238-45.

Patel, M.Z., Reddi, M. V., Rana, B. S. and Reddy, B. J. 1989.Genetic divergence in safflower (Carthamus tinctorius L.).Ind. J.Genet. 49(1): 113-18.

Peeraullee, N. and Ranghoo-Sanmukhiya, V. M. 2013.Assessment of Genetic Diversity in Local Chilli (Capsicum апnиит) varieties in Mauritius. Internal. J. Agric. Biol. 15(5): 891-96.

Ramanujam, S., Tiwary, A. S. and Mehra, R. B. 1974. Genetic divergence and hybrid performance in mungbean. Theor.Appi. Genet. 44(5): 211-14.

Sindhu, J.S., Ahmed, S., Singh, M. B. and Singh, K. P. 1989.Multivariate analysis in blackgram (Vigna mungo L.).Legume Res. 12(1): 35-37. 
Smitha, R. P. and Basavaraja, N. 2006.Genetic Divergence in Chilli (Capsicum annuum L.).Karnataka $J$. Agric. Sci. 19(4): 975-77.

Tomooka, N.1991.Genetic diversity and landraces differentiation of mungbean (Vigna radiate L.) Wilczek and evaluation of its wild relatives (The subgenus Ceratotropics) as breeding materials. Tech. Bull. Trop. Res. Centre, Japan No. 28. Ministry of Agriculture, Forestry and Fisheries. Japan. P.1.

Yatung, T., Dubey, Rakesh K.R., Singh, Vikas and Upadhyay, Garima. 2014. Genetic diversity of chilli (Capsicum annuит L.) genotypes of India based on morpho-chemical traits. Aust. J. Crop Sci. 8(1): 97-102.

\section{How to cite this article:}

Priyanka Bijalwan, Meghana Singh and Naidu Madhavi. 2018. Assessment of Genetic Divergence in Chilli (Capsicum annuum L.) Genotypes. Int.J.Curr.Microbiol.App.Sci. 7(03): 1585-1590. doi: https://doi.org/10.20546/ijcmas.2018.703.190 